\title{
Pre-depulping and depulping treatments and the emergence of queen palm seeds (Syagrus romanzoffiana [Cham.] Glassman)
}

\author{
Tratamiento de pre-despulpado y despulpado \\ sobre la emergencia de semillas de palma reina \\ (Syagrus romanzoffiana [Cham.] Glassman)
}
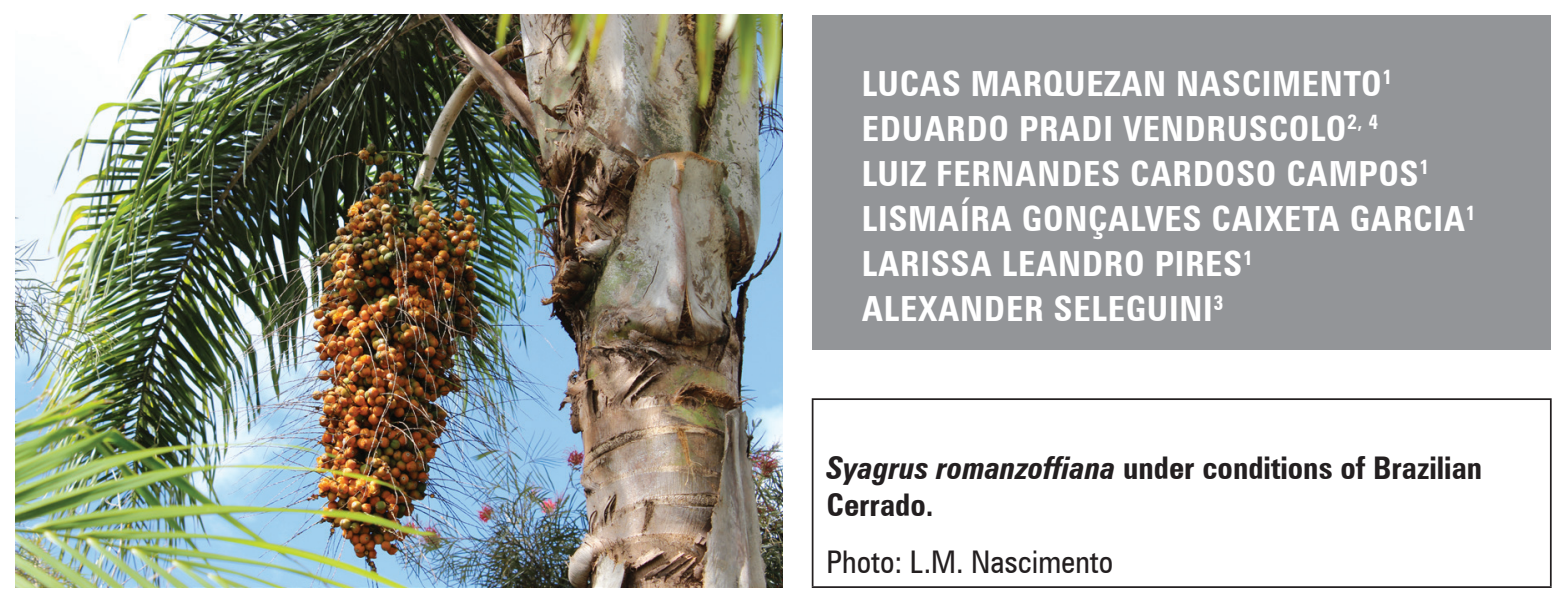

\begin{abstract}
The propagation of the palm Syagrus romanzoffiano is done sexually with seeds, making the process of obtaining new plants slow and difficult, especially on large scales. In addition, seed germination is slow, uneven and susceptible to degradation and loss of vigor because of embryo deterioration, even under laboratory conditions. As a result of the lack of information on efficient depulping methods for queen palm fruits, the present study aimed to establish a depulping methodology that is less aggressive to embryos, maintaining emergence quality. This experiment was carried out in Goiânia, Brazil, using fruits from eight stock plants submitted to three pre-depulping treatments (control, fermentation and drying) and two depulping methods (industrial depulping and concrete-mixer with the addition of gravel). After the different pre-sowing processes, the fresh and dry pyrenes mass, remaining fibers adhered to the pyrene and seedling emergence were evaluated. The pulper removed an average of $45 \%$ more pyrene pulp than the concrete mixer. However, these methodologies did not result in differences in the emergence of plants, which was affected only by the pre-depulping treatment, with superiority in the use of fresh fruits. Thus, the pulper was more efficient for
\end{abstract}

Goiás Federal University, Agronomy School, Goiania (Brazil). ORCID Nascimento, L.M.: 0000-0002-0774-0816; ORCID Campos, L.F.C.: 0000-0001-5171-5194; ORCID Garcia, L.G.C.: 0000-0002-8508-8982; ORCID Pires, L.L.: 00000001-9373-3868

2 Mato Grosso do Sul State University, Cassilândia University Unit, Cassilandia (Brazil). ORCID Vendruscolo, E.P.: 0000-0002-3404-8534

3 Triângulo Mineiro Federal University, Iturama University Campus, Iturama (Brazil). ORCID Seleguini, A.: 0000-00025762-9278

4 Corresponding author. agrovendruscolo@gmail.com 
the removal of pulp and pulp fibers than the concrete mixer. The depulping method did not significantly affect the pyrenes mass. Higher seedlings emergence values were observed for the fresh fruits that were pulped and sown immediately. Fermentation and partial pulp dehydration exert a negative influence on seedling emergence.

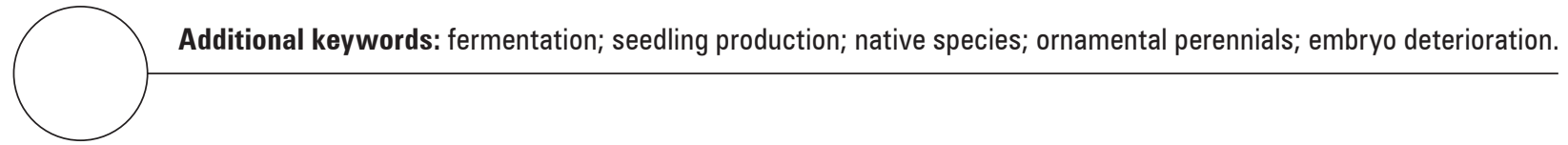

\section{RESUMEN}

La propagación de la palma Syagrus romanzoffiano se realiza sexualmente a través de semillas, lo que hace que el proceso de obtención de nuevas plantas sea lento y difícil, especialmente a gran escala. Además, la germinación de la semilla es lenta, desigual y susceptible a la degradación y pérdida de vigor debido al deterioro del embrión, incluso en condiciones de laboratorio. Debido a la falta de información sobre métodos eficientes de despulpado de frutos de palma reina, con el presente estudio se buscó establecer una metodología de despulpado menos agresiva para el embrión, manteniendo la calidad de la emergencia de las plántulas. El experimento se llevó a cabo en Goiânia, Brasil, utilizando frutas de ocho plantas de stock sometidas a tres tratamientos de pre-despulpado (control, fermentación y secado) y dos métodos de despulpado (despulpado industrial y mezcladora de cemento más grava). Después de los diferentes procesos previos a la siembra, se evaluaron la masa de pirenos frescos y secos, la pulpa restante adherida al pireno y la emergencia de plántulas. Se observó que el despulpado industrial eliminó un promedio de $45 \%$ más de fibra del pireno que la mezcladora de cemento. Sin embargo, estas metodologías no presentaron diferencias en la emergencia de plantas, que se vio afectada solo por el tratamiento pre-despulpado, con superioridad en el uso de frutas frescas. Por lo tanto, se concluye que el despulpado industrial es más eficiente para la eliminación de pulpa y fibras en comparación con el mezclador de cemento. El método de despulpado no afectó significativamente la masa de pirenos. Se observaron valores de emergencia de plántulas más altos para las frutas frescas despulpadas y sembradas inmediatamente. La fermentación y la deshidratación parcial de la pulpa ejercen una influencia negativa en la emergencia de las plántulas.

Palabras clave adicionales: fermentación; producción de plántulas; especies nativas; plantas perennes ornamentales; deterioro del embrión.

Received for publication: 03-09-2018 Accepted for publication: 29-11-2019

INTRODUCTION

The queen palm (Syagrus romanzoffiana [Cham.] Glassman), also known as jerivá, baba-de-boi and pindó, is a native palm of South America, distributed in Brazil, Paraguay, Argentina and Uruguay. In Brazil, this species is found from southern Bahia to the Rio Grande do Sul State in several forest habitats, including in dry areas (Falasca et al., 2012; Lorenzi et al., 2015; Santos and Salomão, 2017; Bruno et al., 2019).

The S. romanzoffiana palm is widely cultivated for ornamental purposes because of its beauty and low maintenance (Downer and Hodel, 2001; Zimmermann et al., 2011; Santos and Salomão, 2017). It has high fruit production that stands out because of its importance as a natural food source for several wild species of birds and frugivorous mammals during periods of food shortages (Silva et al., 2011; Begnini et al., 2013). The fruits are globous, smooth, with a yellow or orange epicarp, and a yellow pulp (mesocarp). They are fleshy-fibrous, sweet flavored, can be consumed in natura in the form of juices and the pulp oil serves as a vitamin A source because of the contents carotenoids and tocopherols (Messias and Alves, 2009; Goudel, 2012; Coimbra and Jorge, 2012; Lorenzi et al., 2015; Santos and Salomão, 2017). It presents a single seed per fruit, protected by a woody endocarp, measuring about 2.4 by $1.6 \mathrm{~cm}$. The seed contains high levels of lipids (more than 50\%), making it possible to obtain biodiesel (Vallilo et al., 2001; Goudel et al., 2013; Moreira et al., 2013). 
The propagation of Arecaceae plants, such as S. romanzoffiana, is done sexually with seeds, which makes the process of obtaining new plants slow and difficult, especially on large scales (Zimmermann et al., 2011; Oliveira, 2014; Lorenzi et al., 2015; Santos and Salomão, 2017). In addition, seed germination is slow, uneven and susceptible to degradation and loss of vigor as a result of embryo deterioration, even under laboratory conditions, possibly because of the crystallization of endosperm lipids (Dewir et al., 2011; Goudel et al. 2013; Oliveira et al. 2015; SilvaCardoso et al., 2017).

The queen palm seed is small and connected to the endocarp with a recess, thus forming the pyrene. Separation without damage to the seed is practically impossible, so it is common for the whole pyrene to be used for S. romanzoffiana propagation (Goudel et al., 2013; Garcia, 2015). Numerous studies with palm seeds recommend before the pyrenes planting use some kind of pulp removal (depulping), either manually (Matteucci, 2007; Dias et al., 2011; Goudel, 2012; Pinheiro et al., 2017; Pernús and Sánchez, 2017; Beltrame et al., 2019), scraping with the aid of sieves (Dewir et al., 2011; Garcia, 2015; Isoschi et al., 2016; Félix et al., 2017; Munhoz et al., 2017) or mechanically with the aid of pulpers (Oliveira, 2014). The aim of depulping is to reduce the incidence of fungi and bacteria that use the fruit pulp (mesocarp + epicarp) as a substrate for its development and end up reducing the germinative embryo potential (Bovi and Bortoletto, 1998); however, there is no methodology specific to the queen palm.

Because of the lack of information on efficient methods of depulping queen palm fruits, the present study aimed to establish a depulping methodology that is less aggressive to the embryo of this species, maintaining emergence quality.

\section{MATERIAL AND METHODS}

This experiment was carried out in the Laboratory of the Horticulture Sector of the Federal University of Goiás, in Goiânia-GO, in 2017. The fruits used in the experiment were from eight stock plants of the queen palm (Syagrus romanzoffiana [Cham.] Glassman), 11 years old, located on private property in the municipality of Anápolis-GO. The experiment design was completely randomized in a $2 \times 3$ factorial scheme (depulping methods'seed lots: pre-depulping). Four replicates were used, 25 seeds per plot.
Bunches were collected with fruits in stage IV maturation (completely orange fruit), according to the maturity point defined by Garcia (2015). The fruits were then separated into three lots: in the first, the fruits were depulped soon after harvesting the bunches containing fresh fruits. In the second batch, the fruits were kept in a shaded place at room temperature for $7 \mathrm{~d}$ (dry in the shade). In the third batch, fruits were placed in a container with water for fermentation in a shaded place, also for $7 \mathrm{~d}$ (fermented fruit).

After the pre-depulping treatments, the fruits were submitted to two depulping methods: one used a mechanical pulper, and the second used a concretemixer with gravel (gravel number 2: between 2 and $64 \mathrm{~mm}$ ). An industrial pulper (Bonina 0.25 DF model, Itametal, Brazil) equipped with a sieve with $0.8 \mathrm{~mm}$ diameter holes and a concrete-mixer (MAOTRONM400 model, Joaçaba, Brazil) with a $1.5 \mathrm{~kW}$ power engine and $400 \mathrm{~L}$ capacity were used.

After the pulp extraction, the material was allowed to dry in a shaded and ventilated place for $4 \mathrm{~d}$. Subsequently, the pulp and remaining fibers were manually separated from the pyrenes (seeds with endocarp attached) with the aid of knives. The pyrenes and fibers were placed in a greenhouse with forced air circulation for $24 \mathrm{~h}$ at $65^{\circ} \mathrm{C}$ to dry. Afterwards, the material was weighed to determine the remaining dry mass that was adhered to the pyrene in each treatment.

To determine the effect of the pre-depulping treatment on seed germination, samples containing 25 seeds per replicate were prepared in plastic perforated trays using medium sand sterilized in an autoclave for $1 \mathrm{~h}$ at $121^{\circ} \mathrm{C}$ and $1 \mathrm{~atm}$ pressure, which were kept in a greenhouse. The sand was moistened with the amount of water equivalent to $60 \%$ of the retention capacity at planting time.

After $330 \mathrm{~d}$, the emerged seedlings that reached adequate transplant size $(25 \mathrm{~cm})$ were quantified. The data were submitted to analysis of variance, and the means were compared by the Tukey test at $5 \%$ probability.

\section{RESULTS AND DISCUSSION}

The pulp and fiber removal from the pulper was significantly more efficient than the concrete mixer, with the fresh fruit being the most difficult to depulp with the concrete mixer (Tab. 1). 
Table 1. Fresh mass (FM) and dry mass (DM) of fibers remaining on queen palm pyrene at different pre-sowing and depulping processes.

\begin{tabular}{|l|c|c|c|c|}
\hline \multirow{2}{*}{\multicolumn{1}{|c|}{ Pre-depulping process }} & \multicolumn{2}{c|}{ FM $(\mathrm{g})$} & \multicolumn{2}{c|}{ DM (g) } \\
\cline { 2 - 5 } & Pulper & Concrete-mixer & Pulper & Concrete-mixer \\
\hline Fresh fruit & $0.33 \pm 0.09 \mathrm{aB}$ & $0.82 \pm 0.09 \mathrm{aA}$ & $0.19 \pm 0.05 \mathrm{aB}$ & $0.51 \pm 0.06 \mathrm{aA}$ \\
\hline Fermented fruit & $0.36 \pm 0.01 \mathrm{aA}$ & $0.39 \pm 0.07 \mathrm{bA}$ & $0.18 \pm 0.03 \mathrm{aB}$ & $0.27 \pm 0.02 \mathrm{bA}$ \\
\hline Fruit dried in the shade & $0.34 \pm 0.12 \mathrm{aB}$ & $0.50 \pm 0.07 \mathrm{bA}$ & $0.22 \pm 0.04 \mathrm{aB}$ & $0.31 \pm 0.03 \mathrm{bA}$ \\
\hline CV (\%) & \multicolumn{2}{|c|}{17.53} & & 13.73 \\
\hline
\end{tabular}

Means with different lowercase letters in the column and uppercase letters in the row indicate significant statistical differences according to the Tukey test $(P \leq 0.05 ; n=4)$. CV $=$ Coefficient of variation; $\pm=$ standard error.

The depulping objective is to remove the maximum amount of the pulp adhered to the pyrene to reduce possible attack by contaminants and predators on the seed since the average pulp percentage in queen palm fruits corresponds to about $60 \%$ of the total fruit weight and has around 65\% moisture (Goudel et al., 2013), providing a food substrate for these organisms. Although the remaining fibers in the fruits were greater in the treatments with the concrete mixer, Oliveira (2014) found that there was no increase in germination with the pore fiber removal since these fibers do not restrict water absorption in queen palm seeds. In addition, the endocarp itself is permeable to water, allowing seeds to acquire or lose moisture within the structure (Baskin and Baskin, 2014; Oliveira et al., 2015; Santos and Salomão, 2017) and offering a physical defense from attack by small rodents (Guimarães et al., 2005). For other Arecaceae (Sabal palmetto e Thrinax morrisii), the fruit pericarp (epicarp, mesocarp and endocarp) presents a certain impermeability to water and, possibly, to oxygen, a limiting factor for seed germination (Dewir et al., 2011), making the removal of these impediment layers via depulping and scarification important.

There was no significant interaction for the mass of the pyrenes for the depulping method used, only for the pre-treatment. For the fresh fruits, lower values were observed for the pyrene fresh mass and dry mass than in the fermented fruits and fruits dried in the shade (Fig. 1). Several authors have indicated that the mean values of queen palm pyrenes dry mass vary from 1.21 to $2.40 \mathrm{~g}$ (Goudel, 2013; Fleury et al., 2015; Garcia, 2015). In the present study, the average dry mass was $1.28 \mathrm{~g}$ although the values of the coefficient of variation (CV) were relatively low, indicating high sample homogeneity. Variation in several characteristics is normal in palms of the same species

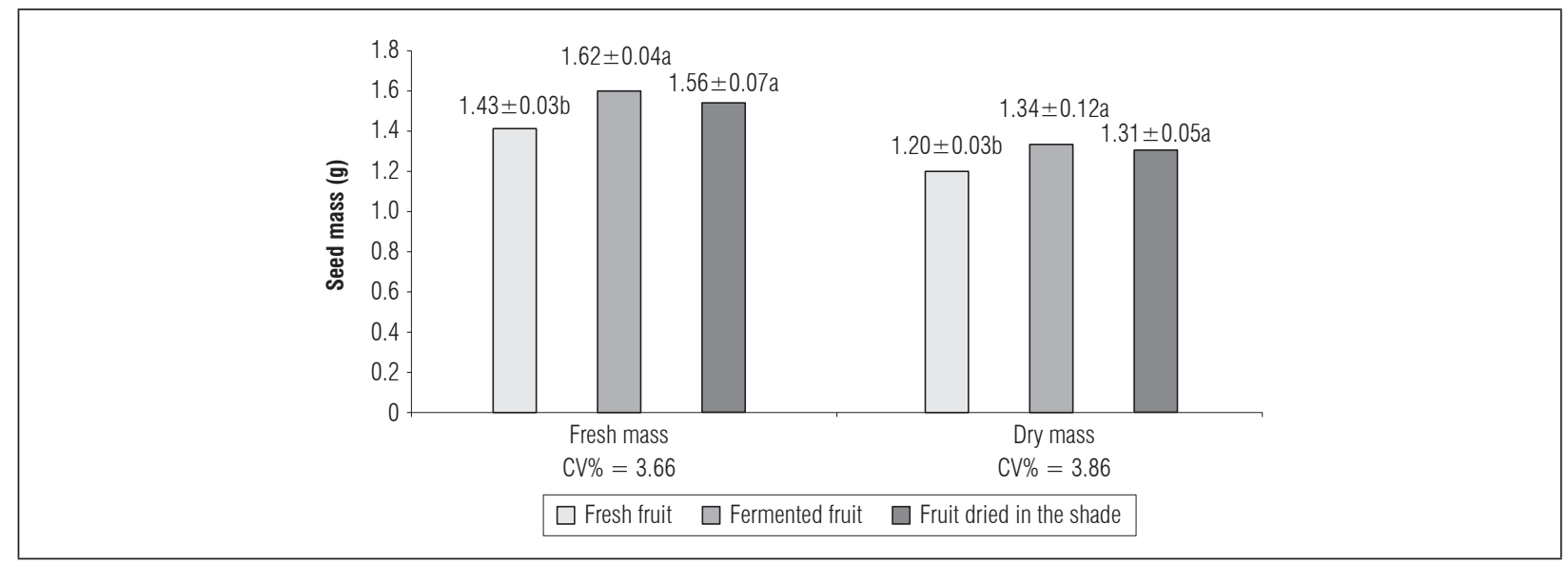

Figure 1. Fresh and dry mass of queen palm pyrenes after different pre-sowing processes. CV = Coefficient of variation; $\pm=$ standard error. 
as a result of environmental factors and genetic variability (Batista et al., 2011a; Mhanhmad et al., 2011).

Fruits used in the experiment had an average moisture content of about $62.6 \%$, and the pulp was responsible for $60 \%$ of the total moisture content of the fruits. A study on $S$. romanzoffiana showed that the pulp corresponds to about $60 \%$ of the total fruit weight and has $66.83 \%$ of the moisture (Goudel et al., 2013). The high moisture content can cause undesirable changes in the physical, chemical and organoleptic characteristics of fruits and seeds (Moura et al., 2010), meaning depulping presents advantage as a seed preservation mechanism. For Euterpe espiritosantensis, the presence of pulp impairs final seed quality during storage (Martins et al., 2000)

For S. romanzoffiana, the highest plant emergence was observed for fresh fruits depulped and immediately sown (62.50\%) (Tab. 2). In the non-depulped pyrene, germination was about 35\% (Goudel et al., 2013). The seeds of freshly harvested ripe queen palm fruits (completely orange) germinate better than stored seeds (Oliveira, 2014), reaching up to $91.25 \%$ germination (Garcia, 2015). For Syagrus oleracea, the germination rate ranges from 50\% to 65\% (Diniz and Sá, 1995; Batista et al., 2011b). The Euterpe precatoria (Arecaceae) fruits sown immediately after harvesting showed the highest germination percentage (Costa et al., 2018). The great variability found in the literature was attributed to the fact that the plant is semidomesticated, with little selection and improvement (Nascente and Peixoto, 2000).

It was observed that fruits dried in a shaded environment presented a low emergence rate when compared to the fresh fruits but were still higher than the fruits with fermented pulp (Tab. 2). The queen palm seed has low longevity and undefined storage behavior (Santos and Salomão, 2017); however, Goudel et al. (2013) did not observe negative effects on the viability and vigor of queen palm seedlings, suggesting a certain tolerance to seed water loss.

The pulp fermentation exerted a negative influence on the seedling emergence. The decrease in germination can be attributed to increased susceptibility to deterioration (Oliveira, 2014), possibly because of the increased humidity. For Archontophoenix alexandrae, fruit depulping after immersion in water for three days provided the highest germination index of freshly harvested seeds, without resulting in large losses in viability (Teixeira et al., 2011). Seed scarification and water immersion over a period of time is efficient at overcoming dormancy and increasing germination rates in Arecaceae (Moussa et al., 1998; Dewir et al., 2011). It is believed that the fruit immersion for seven days in water caused embryo death, possibly by anaerobiosis, cotyledon fermentation or even temperature increases, as a result of fermentation.

Table 2. Emergence of seedling shoots after different presowing processes.

\begin{tabular}{|l|c|}
\hline \multicolumn{1}{|c|}{ Pre-depulping process } & Emergence (\%) \\
\hline Fresh fruit & $62.50 \pm 8.66 \mathrm{a}$ \\
\hline Fermented fruit & $1.25 \pm 2.50 \mathrm{c}$ \\
\hline Fruit dried in the shade & $26.25 \pm 11.09 \mathrm{~b}$ \\
\hline CV (\%) & 34.73 \\
\hline
\end{tabular}

Means with different letters indicate significant statistical difference according to the Tukey test $(P \leq 0.05 ; n=4)$. CV $=$ Coefficient of variation; $\pm=$ standard error.

\section{CONCLUSIONS}

The electric pulper was more efficient for the removal of pulp and pulp fibers than the concrete mixer, with fresh fruits being the most difficult to pulp with the concrete mixer. However, the depulping method did not significantly affect the mass of the pyrenes. Lower values of fresh mass and dry mass of the pyrene were observed in the fresh fruits than in the fermented fruits and fruits dried in the shade. This fermentation and partial pulp dehydration exerted a negative influence on seedling emergence, different from what was obtained with the use of fresh fruits that were sown immediately, which promoted a higher emergence rate.

Conflict of interest. The manuscript was prepared by the authors, who declare that there are no conflicts of interest that put at risk the validity of the results presented here.

\section{BIBLIOGRAFHIC REFERENCES}

Batista, G.S., R.S. Costa, R. Gimenes, K.F.L. Pivetta, and F.V. Môro. 2011a. Aspectos morfológicos dos diásporos e das plântulas de Syagrus oleracea (Mart.) Becc - Arecaceae. Com. Sci. 2(3), 170-176.

Batista, G.S., R.B. Mazzini, R. Gimenes, H.W. Pritchard, and K.F.L. Pivetta. 2011b. Effects of substrate and mechanical scarification on the germination of Syagrus oleracea (Arecaceae) seeds. Seed Sci. Technol. 39, 649654. Doi: 10.15258/sst.2011.39.3.11 
Baskin, J.M. and C.C. Baskin. 2014. What kind of seed dormancy might palms have? Seed Sci. Res. 24, 17-22. Doi: 10.1017/S0960258513000342

Begnini, R.M., F.R. Da Silva, and T. Castellani. 2013. Fenologia reprodutiva de Syagrus romanzoffiana (Cham.) Glassman (Arecaceae) em Floresta Atlântica no sul do Brasil. Biotemas 26(4), 53-60. Doi: 10.5007/2175-7925.2013v26n4p53

Beltrame, R.A., J.M. Jasmim, and H.D. Vieira. 2019. Morphological characterization and germination of Syagrus schizophylla (Mart.) Glass. (ARECACEAE). Comun. Sci. 10(1), 54-64. Doi: 10.14295/CS.v10i1.2997

Bovi, M.L.A. and N. Bortoletto. 1998. Palmito-gariroba: Syagrus oleracea (Mart.) becc. pp. 258-259. In: Fahl, J.I., M.B.P. Camargo, M.A. Pizzinatto, J.A. Betti, A.M.T. Melo, I.C. De Maria, and A.M.C. Furlani (eds.). Instruções agrícolas para as principais culturas econômicas. IAC, Campinas.

Bruno, M.M.A., K.G. Massi, M.M. Vidal, and J. Vall Hay. 2019. Reproductive phenology of three Syagrus species (Arecaceae) in a tropical savanna in Brazil. Flora 252, 18-25. Doi: 10.1016/j.flora.2019.02.002

Coimbra, M.C. and N. Jorge. 2012. Fatty acids and bioactive compounds of the pulps and kernels of Brazilian palm species, guariroba (Syagrus oleraces), jerivá (Syagrus romanzoffiana) and macaúba (Acrocomia aculeata). J. Sci. Food Agric. 92(3), 679-684. Doi: 10.1002/jsfa.4630

Costa, C.R.X., K.F.L. Pivetta, G.R.B. de Souza, R.B. Mazzini-Guedes, S.T.S. Pereira, and M.R. Nogueira. 2018. Effects of temperature, light and seed moisture content on germination of Euterpe precatoria Palm. Am. J. Plant Sci. 9(1), 98-106. Doi: 10.4236/ajps.2018.91009

Dias, T.D., M.S. Conceição, and R.S. De Avila Junior. 2011. Pseudalopex gymnocercus (Carnívora: Canidae) e seu papel dispersor de sementes de Syagrus romanzoffiana (Arecaceae) no RS. In: Anais do $3^{\circ}$ Salão Internacional de Ensino, Pesquisa e Extensão da UNIPAMPA: Salão de Pesquisa. Uruguaiana, Brazil.

Dewir, Y.H., M.E.S. El-Mahrouk, and Y. Naidoo. 2011. Effects of Some Mechanical and Chemical Treatments on Seed Germination of Sabal palmetto and Thrinax morrisii palms. Aust. J. Crop Sci.5 (3), 248-253.

Diniz, J.A. and L.F. Sá. 1995. A cultura da guariroba. EMATER-GO, Goiânia, Brazil.

Downer, J. and D. Hodel. 2001. The effects of mulching on establishment of Syagrus romanzoffiana (Cham.) Becc., Washingtonia robusta $\mathrm{H}$. Wendl. and Archontophoenix cunninghamiana ( $\mathrm{H}$. Wendl.) $\mathrm{H}$. Wendl. \& Drude in the landscape. Sci. Hortic. 87(1-2), 85-92. Doi: 10.1016/ S0304-4238(00)00171-0

Falasca, S.L., C. Miranda del Fresno, and A. Ulberich. 2012. Possibilities for growing queen palm (Syagrus romanzoffiana) in Argentina as a biodiesel producer under semi-arid climate conditions. Int. J. Hydrogen Energy 37(19), 14843-14848. Doi: 10.1016/j. ijhydene.2011.12.092

Félix, F.C., F.S. Araújo, C.S. Ferrari, and M.V. Pacheco. 2017. Dessecação e armazenamento de sementes de Adonidia merrillii (Becc.) Becc. Rev. Bras. Ciênc. Agrár. 12(1), 86-91. Doi: 10.5039/agraria.v12i1a5421

Fleury, M., F. Silla, R.R. Rodrigues, H.T. Couto, and M. Galetti. 2015. Seedling fate across different habitats: The effects of herbivory and soil fertility. Basic. Appl. Ecol. 16(2), 141-151. Doi: 10.1016/j.baae.2014.11.006

Garcia, V.A. 2015. Desenvolvimento e maturação de frutos e sementes de espécies de Arecaceae (Bactris gasipaes Kunth., Euterpe edulis Mart. e Syagrus romanzoffiana (Cham.) Glassman). $\mathrm{PhD}$ thesis. Instituto de Botânica da Secretaria de Estado do Meio Ambiente, São Paulo, Brasil.

Goudel, F. 2012. Caracterização e processamento de mapuitã, os frutos da palmeira jerivá (Syagrus romanzoffiana (Cham.). MSc thesis. Universidade Federal de Santa Catarina, Florianopolis, Brazil.

Goudel, F., M. Shibata, C.M.M. Coelho, and P.R.M. Miller. 2013. Fruit biometry and seed germination of Syagrus romanzoffiana (Cham.) Glassm. Acta Bot. Bras. 27(1), 147-154. Doi: 10.1590/S0102-33062013000100015

Guimarães, P.R., P.F.M. Lopes, M.L. Lyra, and A.P. Muriel. 2005. Fleshy pulp enhances the location of Syagrus romanzoffiana (Arecaceae) fruits by seed-dispersing rodents in an Atlantic forest in south-eastern Brazil. J. Trop. Ecol. 21(1), 109-112. Doi: 10.1017/ S0266467404001932

Isoshi, E., F.V. Moro, B.G.T.L. Vieira, R. Barbosa, and R.D. Vieira. 2016. Chemical composition and tetrazolium test of Syagrus romanzoffiana (Cham.) Glassman seeds. Rev. Bras. Frutic. 38(4), e-550. Doi: 10.1590/0100-29452016550

Lorenzi, H. 2015. Plantas para jardim no Brasil: herbáceas, arbustivas e trepadeiras. $2^{\text {nd }}$ ed. Nova Odesa, Instituto Plantarum.

Martins, C.C., M.L.A. Bovi, J. Nakagawa, and J. Godoy. 2000. Depulping and temperature in seed storage of red-palmito (Euterpe espiritosantensis Fernandes). Rev. Bras. Sementes 22(1), 169-176.

Matteucci, M.B.A., N.N.R. Guimarães, J.B. Duarte, and T.F. Domingos. 2007. Determinação do melhor tratamento para a superação da dormência em guariroba - Syagrus oleracea (Mart) Becc. Pesq. Agropec. Trop. 25(2), 149-153.

Messias, A.D. and A.A. Alves. 2009. Jerivá (Syagrus romanzoffiana - Arecaceae) como oferta de alimento para fauna silvestre em fragmentos de mata ciliar, em período de outono-inverno. Rev. Bras. Biol. 2(1), 35-50. 
Mhanhmad, S., P. Leewanish, V. Punsuvon, and P. Srinives. 2011. Seasonal effects on bunch components and fatty acid composition in Dura oil palm (Elaeis guineensis). Afr. J. Agric. Res. 6(7), 1835-1843.

Moreira, M.A.C., M.P. Arrúa, A.C. Antunes, T.E.R Fiuza, B.J. Costa, P.W. Neto, and S.R.M. Antunes. 2013. Characterization of Syagrus romanzoffiana oil aiming at biodiesel production. Ind. Crop. Prod. 48, 57-60. Doi: 10.1016/j.indcrop.2013.04.006

Moura, R.C., P.S.N. Lopes, D.S. Brandão Junior, J.G. Gomes, and M.B. Pereira. 2010. Fruit and seed biometry of Butia capitata (Mart.) Beccari (Arecaceae), in the natural vegetation of the North of Minas Gerais, Brazil. Biota Neotrop. 10(2), 415-419. Doi: 10.1590/ S1676-06032010000200040

Moussa, H., H.A. Margolis, P. Dube, and J. Odongo. 1998. Factors affecting the germination of doum palm (Hyphaene thebaica Mart.) seeds from the semi-arid zone of Niger, West Africa. For. Ecol. Manag. 104(1-3), 27-41. Doi: 10.1016/S0378-1127(97)00230-2

Munhoz, R.E.F., P. Almeida, F. Negri, G. Rodrigues, L. Capellari, and J.C.P. Mello. 2017. Quebra de dormência em Palmito Juçara (Euterpe edulis). Rev. Uninga. 5(1), 163-169.

Nascente, A.S. and N. Peixoto. 2000. Levantamento de dados sobre guariroba no Estado de Goiás. Hort. Bras. $18,878-879$

Oliveira, T.G.S. 2014. Aspectos ecofisiológicos da germinação e armazenamento de sementes de jerivá (Syagrus romanzoffiana) (Cham.) Glassman. MSc thesis. Universidade Federal de Lavras, Lavras, Brazil.

Oliveira T.G.S., A.C. Jose, L.M. Ribeiro, and J.M.R. Faria. 2015. Longevity and germination of Syagrus romanzoffiana (Arecaceae) seeds and its ecological implications. Rev. Biol. Trop. 63(2), 333-340.

Pernús, M. and J.A. Sánchez. 2017. Germination and seed dormancy of Coccothrinax crinita subsp. crinita
(Arecaceae), endemic palm of Western Cuba. Rev. Jard. Bot. Nac. 38(1), 49-56.

Pinheiro, R. de M., E.A. dos Santos, K.N.O. Moraes, and E.J.L. Ferreira. 2017. Emergência de plântulas e caracterização morfométrica de frutos e sementes de bacabinha (Oenocarpus mapora H. Karsten. Arecaceae). pp. 1529-1543. In: 14 Jornada de Pós-Graduação e Pesquisa, Centro Universitário da Região da Campanha, Bagé, Brasil.

Santos, I.R.I. and A.N. Salomão. 2017. In vitro germination of zygotic embryos excised from cryopreserved endocarps of queen palm (Syagrus romanzoffiana (Cham.) Glassman). In Vitro Cell. Dev. Biol. -Plant. 53, 418-424. Doi: 10.1007/s11627-017-9840-7

Silva, F.R. da, R.M. Begnini, B.C. Lopes, and T.T. Castellani. 2011. Seed dispersal and predation in the palm Syagrus romanzoffiana on two islands with different faunal richness, southern Brazil. Stud. Neotrop. Fauna E. 46(3), 163-171. Doi: 10.1080/01650521.2011.617065

Silva-Cardoso, I.M. de A., A.M. Souza, and J.E. Scherwinski-Pereira. 2017. The palm tree Syagrus oleracea Mart. (Becc.): a review. Sci. Hortic. 225, 65-73. Doi: 10.1016/j.scienta.2017.06.054

Teixeira, M.T., H.D. Vieira, F.L. Partelli, and R.F. Silva. 2011. Despolpamento, armazenamento e temperatura na germinação de sementes de palmeira real australiana. Pesq. Agropec. Trop. 41(3), 378-384. Doi: 10.5216/pat. v41i3.9617

Vallilo, M.I., M. Tavares, S. Aued-Pimentel, M.L. Garbelotti, and N.C. Campos. 2001. Composição química e o perfil de ácidos graxos das sementes de quatro espécies de palmeiras cultivadas no estado de São Paulo. Rev. Inst. Florest. 13(2), 147-154.

Zimmermann, T.G., R.M. Begnini, and F.R. Silva. 2011. Syagrus romanzoffiana (Jerivá). pp. 812-819. In: Coradin, L., A. Siminski, and A. Reis. (Ed.). Espécies nativas da flora brasileira de valor econômico atual ou potencial: plantas para o futuro - Região Sul. Ministério do Meio Ambiente (MMA). Brasilia. 